Discussion Paper No. 10-101

Explaining the Persisting Mathematics Test Score Gap Between Boys and Girls

Maresa Sprietsma

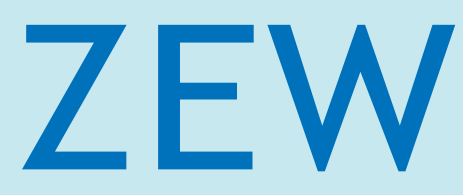

Zentrum für Europäische Wirtschaftsforschung $\mathrm{GmbH}$

Centre for European

Economic Research 
Discussion Paper No. 10-101

\title{
Explaining the Persisting Mathematics Test Score Gap Between Boys and Girls
}

\author{
Maresa Sprietsma
}

Download this ZEW Discussion Paper from our ftp server:

ftp://ftp.zew.de/pub/zew-docs/dp/dp10101.pdf

Die Discussion Papers dienen einer möglichst schnellen Verbreitung von neueren Forschungsarbeiten des ZEW. Die Beiträge liegen in alleiniger Verantwortung der Autoren und stellen nicht notwendigerweise die Meinung des ZEW dar.

Discussion Papers are intended to make results of ZEW research promptly available to other economists in order to encourage discussion and suggestions for revisions. The authors are solely responsible for the contents which do not necessarily represent the opinion of the ZEW. 


\section{Das Wichtigste in Kürze}

Obwohl in den letzten Jahren die Bildungsunterschiede zwischen Jungen und Mädchen gesunken sind, haben Jungen am Ende der Grundschule einen erheblichen Vorsprung in Mathematik. Dies hat langfristige Konsequenzen für die Studienwahl von Mädchen und somit auf die Verfügbarkeit qualifizierter Arbeitskräfte im MINT Bereich.

Obwohl in der US-Literatur verschiedene mögliche Erklärungsfaktoren für den Leistungsunterschied zwischen Jungen und Mädchen in Mathematik untersucht wurden, bleibt die Leistungslücke in Mathematik bisher größtenteils unerklärt. Kulturelle und soziologische Faktoren scheinen aber wichtige Determinanten der Leistungslücke zu sein, da sie nur in bestimmten Bevölkerungsgruppen und Ländern besteht.

Diese Studie liefert Evidenz zum Ursprung der mathematischen Leistungslücke zwischen Mädchen und Jungen auf Grundlage der erweiterten PISA Daten für Deutschland. Zunächst wird der Effekt des Anteils der MathematikLehrerinnen an allen Mathematik-Lehrern in der Sekundarschule auf die Leistungslücke analysiert. Es wird häufig behauptet, dass Schüler eine bessere Leistung erbringen, wenn sie von Lehrern des gleichen Geschlechts unterrichtet werden. Die bestehende Evidenz dazu ist jedoch nicht eindeutig. Ein höherer Anteil an Mathematik-Lehrerinnen könnte ein positives Vorbild für Mädchen darstellen. Außerdem könnten die Lehrerinnen didaktische Methoden anwenden, die für Mädchen besser geeignet sind, oder sie könnten größere Erwartungen an die mathematische Leistung von Mädchen haben als männliche Lehrer.

Darüber hinaus wird in einen nächsten Schritt untersucht, wie Unterschiede zwischen Mädchen und Jungen beim Selbstvertrauen und bei der extrinsischen Motivation in Bezug auf Mathematik mit der Leistunglücke zusammenhängen. Obwohl Mädchen im Durchschnitt mehr Bücher zuhause haben, öfter das Gymnasium besuchen und länger in den Kindergarten gehen, ergibt sich, dass sie weniger an ihre Leistungsfähigkeit glauben als Jungen. Darüber hinaus glauben Jungen öfter, dass sie Mathematik in ihrem zukünftigen Beruf brauchen werden.

Es wird kein Effekt des Anteils der Lehrerinnen auf die Leistungslücke gefunden. Eine Erhöhung des Anteils der Mathematik-Lehrerinnen in der Sekundarschule scheint also keine effektive Lösung um die Leistungsunterschiede zu verringern. Im Unterschied zu diesem ersten Ergebnis scheinen das geringere Selbstvertrauen und die extrinsische Motivation bezüglich Mathematik bei Mädchen zur Erklärung der Leistungslücke beizutragen. Um die Relevanz der geschlechtsspezifischen Wahrnehmung des Fachs Mathematik weiter zu untersuchen, ist in Zukunft die Zusammenarbeit mit Psychologen erforderlich. 


\section{Non-technical summary}

Although the educational attainment gap between boys and girls has been reduced in the last years, boys still outperform girls in mathematics starting from the end of primary school. This has lasting consequences for the availability of skilled workers in technical and innovative fields because mathematic skills influence the choice of majors. Moreover, from the individual point of vue, mathematic skills yield high returns on the labour market.

Although several possible determinants of the difference in mathematical performance between boys and girls have been investigated in the US literature, the test score gap in mathematics has remained largely unexplained as yet. Nevertheless, there are reasons to believe that cultural factors play a role in the development of the test score gap, and that it cannot entirely be due to genetic differences in ability. Firstly, because the mathematics test score gap is non significant in kindergarten and develops during the primary school years, and because the gap seems to occur only in certain subgroups of the population.

This paper contributes to the literature by providing new evidence on the sources of the gender test score gap in mathematics using detailed information on teachers and pupils from the complementary national PISA survey in Germany. Firstly, we investigate whether the share of female mathematics teachers affects the mathematics test score gap. The idea is that a higher share of female mathematics teachers may provide a positive role model for female pupils. In addition, female mathematics teachers may use didactical methods that are more adapted to girls and they could have less prejudice towards girls performance in mathematics than male teachers.

In a second step, detailed information on parents and pupils perception of mathematics allows us to investigate the role of self-confidence and extrinsic motivation in the appearance of the test score gap in mathematics. Although girls on average face more favorable learning conditions with respect to the number of books at home, the type of secondary school, the time spent in kindergarten and even parental expectations, we find that they have less confidence in their math skills than boys. Moreover, boys believe more often than girls that they will need mathematics skills in their future jobs

We do not find a significant effect of the share of female mathematics teachers in secondary school on the gender test score gap in mathematics. Based on these results, it seems ineffective to increase the share of female mathematics teachers to reduce the test score gap. To the contrary, the gender test score gap is reduced by more than half when parents have more than 500 books at home. Female pupils' lower extrinsic motivation and self-confidence in mathematics also seem to account for part of the test score gap. In order to go further in the exploration of the reasons behind the development of beliefs about differences in talent in mathematics between boys and girls, we believe future research should be done in cooperation with psychologists. 


\title{
Explaining the Persisting Mathematics Test Score Gap Between Boys and Girls
}

\author{
Maresa Sprietsma ${ }^{*}$
}

7th December 2010

\begin{abstract}
This paper provides evidence on the sources of the persisting mathematics test score gap between boys and girls. In particular, we investigate the role of the share of female mathematics teachers in secondary school and of pupils self-confidence and extrinsic motivation in mathematics. We find that the share of female mathematics teachers does not seem to affect differences in test scores between boys and girls. The number of books at home as well as the included psychological factors significantly reduce the gender test score gap. A remaining gap of $14 \%$ of a standard deviation in test scores is unexplained.
\end{abstract}

\section{JEL-Classification: I28}

Keywords: mathematics test score gap, gender, share of female teachers, self-confidence

*Centre for European Economic Research (ZEW), P.O. Box 103443, D-68034 Mannheim, Germany, sprietsma@zew.de.

$\dagger$ Acknowledgements: I would like to thank Julia Horstschräer and Katja Coneus for their comments on earlier versions of this paper. The usual disclaimer applies. 


\section{Introduction}

Although the educational attainment gap between boys and girls has been reduced in the last years, boys still outperform girls in mathematics starting from the end of primary school (Husain and Millimet, 2009). This has lasting consequences for female pupils, because mathematic skills yield high returns on the labour market (Goodman, 2008; Edmark and Skans, 2009; Joensen and Nielsen, 2009). Several possible determinants of the difference in mathematic performance between boys and girls have been investigated in the US literature. Teachers' expectations and resulting attitudes, as well as differences in the optimal didactical methods by gender are thought to contribute to creating the test score gap in mathematics. Recent papers have investigated the effect of the pupil-teacher gender match (Ammermüller and Dolton, 2006; Dee, 2007), gender stereotypes in grading (Lavy, 2008), or early tracking (Pekkarinen, 2008).

However, as yet the test score gap in mathematics has remained largely unexplained. Biased grading seems to act in favor of girls (Lavy, 2008), lower parental expectations as to female mathematic performance do not seem to affect the test score gap, and parents invest the same amount of time in mathematics-related activities with boys and girls in the US (Fryer and Levitt, 2010). Results concerning the individual pupil-teacher gender match are mixed (Ammermüller and Dolton, 2006; Dee, 2007). Nevertheless, there are reasons to believe that cultural factors play a role in the development of the test score gap, and that it cannot entirely be due to genetic differences in ability. Firstly, because the mathematics test score gap is non significant in kindergarten and develops during the primary school years, and because the gap seems to occur only in certain subgroups of the population, such as among white pupils for the US, and in Western European countries (Husain and Millimet, 2009; Fryer and Levitt, 2010).

This paper contributes to the literature by providing new evidence on the sources of the gender test score gap in mathematics using detailed information on teachers and pupils from the complementary national PISA survey in Germany. Firstly, we investigate whether the share of female mathematics teachers affects the mathematics test score gap. The idea is that a higher share of female mathematics teachers may provide a positive role model for female pupils. In addition, female mathematics teachers may use didactical methods that are more adapted to girls and they could have less prejudice 
towards girls performance in mathematics than male teachers. The role of teacher expectations on pupil performance has been well documented in the psychological literature since Rosenthal and Jacobson (1968). In a second step, detailed information on pupils and parents perception of mathematics allows us to go further in the exploration of the role of self-confidence and extrinsic motivation in the appearance of the test score gap in mathematics. The paper is organised as follows: Section 2 presents the data and descriptive statistics, Section 3 presents the estimation strategy, Section 4 contains the results, and Section 5 concludes.

\section{Data and descriptive statistics}

We use the PISA 2003 national complementary questionnaire for Germany $\left(\right.$ PISA- $\left.\mathrm{I}^{1}\right)$. Besides the usual standardised test scores in mathematics, reading, science and problem-solving for a representative sample of 15 year olds, the data contain additional information with respect to pupils, parents and teachers as compared with the international PISA data. Amongst other variables, detailed information is available on teacher education and taught disciplines, and both parents and pupils are asked about their selfconfidence and other feelings towards mathematics (PISA Konsortium Deutschland, 2006).

We observe up to ten randomly selected mathematics teachers in a given school. If fewer than ten mathematics teachers are present in the school, the remaining questionnaires are given to teachers of other disciplines. We therefore do not have a complete sample of teachers of other disciplines and focus only on mathematics teachers. Unfortunately, we cannot observe the individual pupil-teacher match. We therefore use the teacher data to construct the share of female mathematics teachers in school as well as the school average of mathematics teacher characteristics by gender. For instance, we observe teacher experience, education, and teacher grades at their final examination. We then merge the aggregated teacher dataset with the pupil and school data. Excluding missing values for the control variables, the sample is reduced from 4660 to 2997 observations $^{2}$.

\footnotetext{
${ }^{1}$ These data are made available by the Research Data Centre (Forschungsdatenzentrum, FDZ) at the Institute for Educational Progress (Institut zur Qualitätsentwicklung im Bildungswesen, IQB).

${ }^{2}$ The results for the main explanatory variables share of female mathematics teachers
} 
Table 1 presents the average difference in test scores between boys and girls in maths by number of books at home, type of secondary school ${ }^{3}$ and share of female mathematics teachers in the school. The PISA data provide five different measures of test scores in mathematics, all are standardized to have a mean of 500 and a standard deviation of a 100 points. On average, girls obtain significantly lower grades in mathematics than boys and the magnitude of the test score gap is similar for the three most common types of secondary school (about 33\% of a standard deviation in test scores). However, the size of the test score gap decreases with the number of books at home. This supports the argument that the observed difference in mathematics performance between boys and girls is not due to biological differences in aptitude alone. The average test scores boys and girls is not significantly different in schools with more or less than $50 \%$ female teachers.

Table 1: The gender test score gap in mathematics, descriptive statistics

\begin{tabular}{l|cc|c|c}
\hline & $\begin{array}{c}\text { Test score } \\
\text { girls }\end{array}$ & $\begin{array}{c}\text { Test score } \\
\text { boys }\end{array}$ & $\begin{array}{c}\text { Test } \\
\text { score gap }\end{array}$ & Obs. \\
\hline \hline All pupils & 522,7 & 541,9 & 19,2 & 2997 \\
\hline$<100$ books at pupil's home & 481,5 & 507,4 & 25,9 & 1329 \\
$101-500$ books at pupil's home & 546,2 & 570,2 & 24 & 1256 \\
$>500$ books at pupil's home & 570,8 & 581,9 & 11,2 & 412 \\
\hline Hauptschule & 410,4 & 444,8 & 34,5 & 495 \\
Realschule & 501 & 534 & 33,1 & 1057 \\
Mixed secondary school & 478,2 & 519,5 & 41,4 & 264 \\
Gymnasium & 581,5 & 614,6 & 33,1 & 1181 \\
\hline$<50 \%$ female math teachers & 527,5 & 546,7 & 19,2 & 1947 \\
$>50 \%$ female math teachers & 514,8 & 531,9 & 17,1 & 1050 \\
\hline
\end{tabular}

Note: Averages over the five measures of mathematics test scores. Own calculations.

\section{$3 \quad$ Estimation strategy}

In a first step, we want to study the effect of the share of female mathematics teachers on the mathematics test score gap between boys and girls. We do not

and number of books at home are similar when using the larger sample.

${ }^{3}$ Pupils are separated into different tracks at between 10 and 12 years old. 
observe the gender of a specific pupil's teachers over his school career but the vast majority of primary school teachers are female. It is therefore unlikely that a role model disadvantage emerges for girls due to teacher gender in primary school. Table 2 presents some average teacher characteristics by gender. It appears that there are differences in the observable characteristics of male and female mathematics teachers. Male teachers on average have four years more experience whereas female teachers have better secondary school grades. The share of mathematics teachers that had mathematics as a major during their studies ${ }^{4}$ as well as the obtained grade at the final examination is the same among men and women.

Table 2: Teacher characteristics, by gender

\begin{tabular}{l|c|c|c|c}
\hline & $\begin{array}{c}\text { Female } \\
\text { math } \\
\text { teachers }\end{array}$ & $\begin{array}{c}\text { Male math } \\
\text { teachers }\end{array}$ & $\begin{array}{c}\text { Number of } \\
\text { schools }\end{array}$ & Difference \\
\hline \hline Average years of experience & 17,1 & 21,7 & 110 & $* * *$ \\
Share that studied math & 0,86 & 0,82 & 110 & 110 \\
Average 2ndary school grade & 2,5 & 2,8 & 103 & $* * *$ \\
Average grade final math exam & 2,3 & 2,3 & $* *$ \\
\hline
\end{tabular}
Note: Grades are measured on the German scale from 1 (very good) to 6 (very bad).*** stands for statistical significance of the difference at the $1 \%$ confidence level. The number of schools is that where the variable is observed for both male and female teachers.

We argue that the share of female mathematics teachers is exogenous with respect to pupil performance. In effect, teachers are assigned to schools by a centralised system in Germany. Teachers may submit applications for a ranking of preferred schools. The better the grades a teacher obtained at the final examination, the higher priority is given to his or her preferences. Schools cannot choose their preferred candidate, they have to take the teacher from the list of applicants that has the highest grades. Therefore, the gender composition of the teacher team can be argued to be exogenous to pupil test scores. Schools may exceptionnally advertise positions for specific pedagogical needs. In our data, this is the case for $5.5 \%$ of schools. We include a dummy variable taking the value of one if the school occasionally hires teachers outside the centralised system. A further potential issue is

\footnotetext{
${ }^{4}$ Teachers do not always teach the disciplines they studied for.
} 
that some schools may have a good reputation and therefore be the favorite choice of many teachers. These schools could attract the best teachers in the described system. As a consequence, we control for the average teacher final examination grades in mathematics in our estimation.

The baseline estimated equation for pupil i in school s thus reads:

$$
\begin{aligned}
\text { MathsScore }_{i s}= & \alpha_{i s}+\text { Female }_{i}+\sum_{j=2}^{4} \text { Sharefemteacher }_{s j} \\
& + \text { PupilVar } \\
i & + \text { SchoolVar }_{s}+\gamma_{s}+\varepsilon_{i s}
\end{aligned}
$$

In a second specification, we also include interaction effects of the shares of female teachers with pupil gender, in order to investigate whether girls respond differently to the share of female mathematics teachers than boys.

The PISA data provide five different measures of test scores in mathematics. Regressions are performed for all 5 measures of test scores and the presented coefficients are the average across these 5 regressions, as is common practice and recommended by the PISA data documentation.

In a following step, we focus on the belief of the pupil in his/her own mathematics skills, anxiety with respect to mathematics, and the belief that one will need mathematics in one's future job as possible sources of the test score gap in mathematics. Other available variables include the relative time spent on mathematics homework, as well as parental interest in mathematics and the degree of support to their child in mathematics. All these variables are based on the aggregation of the answers to a series of items. We construct the mean of the answers to the items available for a given question (if the answer to a given item is missing the mean is calculated based on the other items). The results we obtain for these variables are descriptive in nature, their effect cannot be separated from that of unobserved pupil characteristics that they may correlate with. 


\section{Results}

\section{The share of female teachers}

We start by estimating mathematics test scores as a function of the share of female mathematics teachers in the school. Table 3 presents the results of a regression of the explanatory variables on mathematics test scores, including crossed effects with pupil gender. We note that the raw test score difference between boys and girls from Table 1 is much smaller than that obtained when including control variables in Table 3. Girls on average attend higher secondary school tracks, attend kindergarten for a longer time, and their schools on average have a lower percentage of migrants (as can be observed in Table 4). Because of these advantages, the conditional performance gap in mathematics is larger than the raw test score gap.

The results in Table 3 show that the proportion of female mathematic teachers does not have a significant effect on test scores. Neither are crossed effects of pupil gender with the proportion of female mathematics teachers significantly different from zero. Other specifications including the share of mathematics hours taken over by female teachers, or a continuous variable measuring the share of female teachers qualitatively yield similar results. Girls performance is thus not affected differently by the presence of many female mathematics teachers as compared to boys. Based on these results, it seems ineffective to increase the share of female mathematics teachers to reduce the test score gap.

Studies looking at the individual teacher-student gender match yielded some evidence of positive effects of having a same gender mathematics teachers (Dee, 2007; Ammermüller and Dolton, 2006). A possible interpretation is therefore that the teacher gender effects only appear if the pupil's own teacher is of the same gender, i.e. the effect of the share of female mathematics teachers cannot be measured because it only affects those pupils that have a female teacher. Alternatively, it could be the case that female teachers hold and transmit the same expectations about girls skills in mathematics as male teachers and/or that role models do not play a role in Germany. Ammermüller and Dolton (2006) indeed find individual student teacher gender match to have an effect only in England, but not in the US. It would be interesting to control for the teachers' beliefs about differences in talent in mathematics between boys and girls, but this information is not included in the data. 
The included control variables have the expected signs and magnitude. They include the pupil's grade and type of secondary school track, class size in mathematics as well as the share of non native german speaking pupils in the school, the school's educational material, a dummy for full-time employment of the father and a dummy for attending kindergarten for less than one year. In particular the number of books at home is largely positively correlated with test scores as is usual in the education production function literature ${ }^{5}$. The share of mathematics teachers that studied mathematics as a major is not related to test scores, but the average final examination grade is. School where teachers obtained performed less well at their final examinations (i.e. obtained higher grades in the German system) have lower math performance. This could reflect the previously mentionned selection of teachers into schools that have a good reputation.

\footnotetext{
${ }^{5}$ It is generally considered a proxy for the interest and value given to learning and education by the parents.
} 
Table 3: The effect of the share of female mathematics teachers on test scores

\begin{tabular}{|c|c|c|}
\hline & (1) & (2) \\
\hline Female & $\begin{array}{c}-38,0 * * * \\
(2,9)\end{array}$ & $\begin{array}{c}-35,7 * * * \\
(5,5)\end{array}$ \\
\hline $101-500$ books at pupil's home & $\begin{array}{c}26,2 * * * \\
(3,3)\end{array}$ & $\begin{array}{c}26,3 \text { *** } \\
(3,3)\end{array}$ \\
\hline$>500$ books at pupil's home & $\begin{array}{c}29,9 * * * \\
(5,3)\end{array}$ & $\begin{array}{c}30,0 * * * \\
(5,3)\end{array}$ \\
\hline $25-50 \%$ female math teachers & $\begin{array}{l}-1,4 \\
(6,3)\end{array}$ & $\begin{array}{c}2,0 \\
(7,0)\end{array}$ \\
\hline $50-75 \%$ female math teachers & $\begin{array}{c}3,0 \\
(6,8)\end{array}$ & $\begin{array}{c}2,7 \\
(7,8)\end{array}$ \\
\hline More than $75 \%$ female math teachers & $\begin{array}{l}-7,7 \\
(9,4)\end{array}$ & $\begin{array}{l}-13,3 \\
(10,5)\end{array}$ \\
\hline Female*25-50\% female math teachers & & $\begin{array}{l}-6,6 \\
(7,1)\end{array}$ \\
\hline Female*50-75\% female math teachers & & $\begin{array}{l}-0,1 \\
(8,1)\end{array}$ \\
\hline Female $^{*}>75 \%$ female math teachers & & $\begin{array}{c}1,8 \\
(10,2)\end{array}$ \\
\hline School chooses teachers & $\begin{array}{l}-8,6 \\
(7,2)\end{array}$ & $\begin{array}{l}-8,7 \\
(7,2)\end{array}$ \\
\hline Share of math teachers that studied math & $\begin{array}{c}12,6 \\
(15,6)\end{array}$ & $\begin{array}{c}12,3 \\
(15,6)\end{array}$ \\
\hline Average grade math teachers at final exam & $\begin{array}{c}-11,8 * \\
(6,1)\end{array}$ & $\begin{array}{c}-11,9 * \\
(6,1)\end{array}$ \\
\hline Constant & $\begin{array}{l}-13,4 \\
(28,2)\end{array}$ & $\begin{array}{l}-14,0 \\
(28,1)\end{array}$ \\
\hline R-squared & 0,52 & 0,52 \\
\hline Number of observations & 2997 & 2997 \\
\hline
\end{tabular}

Note: Dependent variable : mathematics test scores. Each estimation is performed with the 5 available measures of test scores, the presented coefficients are the average over the 5 estimations. Standard errors are clustered by school. *, **, *** respectively stand for statistical significance at the 10,5 and $1 \%$ confidence level. Control variables include the pupil's grade, secondary school track, mathematic class size, the share of migrants in the school, school's educational material, a dummy for full-time employment of the father and a dummy for attending kindergarten for less than one year. 


\section{Exploring the role of psychological factors in explaining the gender test score gap in mathematics}

We next try to discover whether differences in self-confidence and extrinsic motivation (as measured by the belief to need mathematics in their future job) or differences in parental attitudes and support in mathematics contribute to generating a test score gap between boys and girls.

Table 4 presents descriptive statistics of the available variables by gender. It appears that many differences exist in the beliefs and feelings towards mathematice between boys and girls. Although girls on average face more favorable learning conditions with respect to the number of books at home, the type of secondary school, the time spent in kindergarten and even parental expectations, they seem to have less confidence in their math skills than boys. Girls present a significantly higher level of anxiety in mathematics, and believe they have less skills. Finally, boys more often believe that they will need mathematics skills in their future jobs and parental support (as measured by helping out when the child has problems) in mathematics is stronger for boys. Only the relative amount of time spent on mathematics homework is the same for girls and boys. 
Table 4: Descriptive statistics by pupil gender

\begin{tabular}{|c|c|c|c|}
\hline & Girls & Boys & Difference \\
\hline $\begin{array}{l}\text { Share of non native speakers in school } \\
\text { (on a scale of } 1:<10 \% \text { to } 4 \text { : more than } 40 \% \text { ) }\end{array}$ & 3,52 & 3,40 & $* * *$ \\
\hline $\begin{array}{l}\text { Number of books at home } \\
\text { (on a scale of } 1:<100 \text { to } 3:>500 \text { ) }\end{array}$ & 1,72 & 1,66 & $* *$ \\
\hline Attend the hightest school track (Gymnasium) & 0,43 & 0,35 & $* * *$ \\
\hline Less than one year in kindergarten & 0,13 & 0,17 & $* * *$ \\
\hline $\begin{array}{l}\text { Parental interest in math } \\
\text { (on a scale of } 1 \text { :disagree to } 4 \text { : fully agree) }\end{array}$ & 2,43 & 2,54 & $* * *$ \\
\hline $\begin{array}{l}\text { Parental support in math } \\
\text { (on a scale of } 1 \text { :disagree to } 4 \text { : fully agree) }\end{array}$ & 3,06 & 3,15 & $* * *$ \\
\hline $\begin{array}{l}\text { Expected educational attainment (parents) } \\
\text { (on a increasing scale of } 1 \text { to } 4 \text { ) }\end{array}$ & 2,87 & 2,76 & $* * *$ \\
\hline $\begin{array}{l}\text { Anxiety in mathematics } \\
\text { (on a scale of } 1: \text { disagree to } 4: \text { fully agree) }\end{array}$ & 2,29 & 1,99 & $* * *$ \\
\hline $\begin{array}{l}\text { Belief in own math skills } \\
\text { (on a scale of } 1 \text { :disagree to } 4 \text { : fully agree) }\end{array}$ & 2,35 & 2,74 & $* * *$ \\
\hline $\begin{array}{l}\text { Need mathematics in future job } \\
\text { (on a scale of } 1 \text { :disagree to } 4 \text { : fully agree) }\end{array}$ & 2,69 & 3,03 & $* * *$ \\
\hline Relative time spent on math homework & 0,47 & 0,48 & \\
\hline
\end{tabular}

Note: ${ }^{*},{ }^{* *},{ }^{* * *}$ respectively stand for statistical significance at the 10,5 and $1 \%$ confidence level. Parental interest in mathematics taken from the parents questionnaire. Expected educational attainment is the type of secondary school certificate the parents expect their child to obtain (4 types exist: Hauptschule, Realschule, mixed school and Gymnasium).

Including a crossed effect of the number of books at home and gender, it appears that the gender test score gap is reduced by more than half when parents have more than 500 books at home (column 2 in Table 5). The number of books at home is often interpreted as a proxy for parents' own interest in learning but it remains to be explained how parental attitudes help girls to perform better in mathematics. The included variables are all significantly correlated with mathematics test scores (Table 5). Following their inclusion, the gender test score gap is reduced by $28 \%$ (from 44 to 32 percent of a deviation in test scores). It does therefore seem to be the case that the lower level of self-confidence and extrinsic motivation of girls is responsible for 
some of the test score gap. The positive effect of the number of books at home is reduced in this specification and thus seems partly related to higher self-confidence and extrinsic motivation of girls in mathematics. However the crossed effect of gender and the number of books at home remains strongly significant. As a consequence, the number of books at home must relate to girls performance in mathematics through other channels as well. The remaining test score gap with the inclusion of all 'psychological' variables for girls that have more than 500 books at home is of around 14 percent of a standard deviation in test scores.

Our findings seem compatible with evidence from the psychological literature about the role of stereotypes in generating differences in performance by gender. Dweck (2006) for instance found that boys and girls performed equally well at tests when they did not believe in mathematic skills as a gift but rather as something they could develop. Unfortunately, no information is available on the beliefs of pupils, parents or teachers as to talent in mathematics in boys versus girls. These beliefs are likely to affect the pupils self-image and motivation, in a similar way as teacher expectations do (Rosenthal and Jacobson, 1968). We think interdisciplinary cooperation is necessary to further investigate the relation between the number of books at home, beliefs and the gender test score gap.

Finally, we use information on maternal occupation in order to investigate whether maternal professional status affects the gender test score gap. Maternal occupation could provides a role model to girls or may be related to parental beliefs as to gender specific ability in mathematics. We therefore present a regression where we include the type of occupation the mother has. The majority of the mothers in our sample $(52 \%)$ work in the low skilled services or social sector (hairdressers, cleaning, nurses, school or kindergarten teachers). A further $12 \%$ are housewives, the remaining work in high skilled or office jobs as employees. As can be seen in Table 6, the professional status of mothers does not seem correlated with the gender test score gap. However, this measure of occupation is very broad, additional information on tasks could yield other results. 
Table 5: Other determinants of the mathematics test score gap

\begin{tabular}{|c|c|c|c|}
\hline & (1) & $(2)$ & (3) \\
\hline Female & $\begin{array}{c}-38,1 * * * \\
(3,0)\end{array}$ & $\begin{array}{c}-44,4 * * * \\
(4,1)\end{array}$ & $\begin{array}{c}-32,0 * * * \\
(3,8)\end{array}$ \\
\hline $101-500$ books at pupil's home & $\begin{array}{c}26,6 * * * \\
(3,3)\end{array}$ & $\begin{array}{c}23,1 * * * \\
(4,5)\end{array}$ & $\begin{array}{c}19,7 * * * \\
(4,2)\end{array}$ \\
\hline$>500$ books at pupil's home & $\begin{array}{c}29,7 * * * \\
(5,4)\end{array}$ & $\begin{array}{c}16,5 * * * \\
(6,0)\end{array}$ & $\begin{array}{c}16,2 * * * \\
(5,5)\end{array}$ \\
\hline Female* $>100-500$ books at home & & $\begin{array}{c}6,8 \\
(5,4)\end{array}$ & $\begin{array}{c}4,9 \\
(5,0)\end{array}$ \\
\hline Female $^{*}>500$ books at home & & $\begin{array}{c}24,8 * * * \\
(7,6)\end{array}$ & $\begin{array}{c}18,1 * * * \\
(7,0)\end{array}$ \\
\hline Belief in own mathematics skills & & & $\begin{array}{c}19,1 * * * \\
(2,9)\end{array}$ \\
\hline Anxiety towards mathematics & & & $\begin{array}{c}-15,9 * * * \\
(2,9)\end{array}$ \\
\hline Believes to need math for future job & & & $\begin{array}{c}-6,4 * * * \\
(2,0)\end{array}$ \\
\hline Parental interest in mathematics & & & $\begin{array}{l}4,3 * \\
(2,0)\end{array}$ \\
\hline Parental support in mathematics & & & $\begin{array}{c}-9,4 * * * \\
(2,1)\end{array}$ \\
\hline Relative time spent on math homework per week & & & $\begin{array}{c}-21,5 * * * \\
(5,1)\end{array}$ \\
\hline Constant & $\begin{array}{l}-38,0 \\
(25,2) \\
\end{array}$ & $\begin{array}{c}-35,2 \\
(25,3) \\
\end{array}$ & $\begin{array}{c}45,8 \\
(28,7) \\
\end{array}$ \\
\hline R-squared & 0,51 & 0,51 & 0,58 \\
\hline Number of observations & 2997 & 2997 & 2997 \\
\hline
\end{tabular}

Note: Dependent variable : mathematics test scores. Each estimation is performed with the 5 available measures of test scores, the presented coefficients are the average over the 5 estimations. Standard errors are clustered by school.*, **, *** respectively stand for statistical significance at the 10,5 and $1 \%$ confidence level. Control variables include the pupil's grade, secondary school track, mathematics class size, the share of migrants in the school, school's educational material, a dummy for full-time employment of the father and a dummy for attending kindergarten for less than one year. 


\section{Conclusion}

Investigating the sources of the gender test score gap in mathematics we do not find a significant effect of the share of female mathematics teachers in school on the gender test score gap in mathematics. Increasing the share of female mathematics teachers in secondary school is therefore not a solution to reduce the mathematics test score gap. This is consistent with existing findings for primary school, where the gender test score gap develops although most primary school teachers are female. One possible interpretation is that female and male teachers transmit similar stereotypes about gender-related differences in talent in mathematics or that role models are not relevant for the acquisition of mathematic skills. Alternatively, it could be the case that teacher gender effects only appear if the pupil's own teacher is of the same gender, i.e. we do not measure an effect because we only look at the share of female mathematics teachers.

Moreover, we find that the gender test score gap decreases with the number of books at home and that it is related to differences in male and female pupils' extrinsic motivation and self-confidence in mathematics. This is in line with the absence of an effect in certain countries and population groups found in the literature since gender differences in extrinsic motivation and self-confidence in mathematics are likely to be culturally determined. Further investigation is needed on the origins of beliefs about differences in talent in mathematics between boys and girls and the relation between the number of books at home and beliefs. Such research will be most effectively done in cooperation with psychologists. 


\section{References}

Ammermüller, A. and Dolton, P. (2006). Pupil-teacher gender interaction effects on scholastic outcomes in England and the USA. ZEW Discussion Paper, 06-060.

Dee, T. (2007). Teachers and the gender gaps in student achievement. Journal of Human Resources, 42(3):528-554.

Dweck, C. (2006). Why aren't more women in science? Top researchers debate the evidence, chapter Is math a gift? Beliefs that put females at risk. Washington, DC: American Psychological Association, S.J. Ceci and W. Williams edition.

Edmark, K. and Skans, O. N. (2009). Math and money: The causal effects of high school math on labor market outcomes. IFAU Working Paper.

Fryer, R. G. and Levitt, S. D. (2010). An empirical analysis of the gender gap in mathematics. American Economic Journal: Applied Economics., $2(2): 210-40$.

Goodman, J. (2008). The labor of division: Returns to compulsory math coursework. Columbia Working Paper.

Husain, M. and Millimet, D. (2009). The mythical 'boy crisis'? Economics of Education Review, 28:34-48.

Joensen, J. S. and Nielsen, H. S. (2009). Is there a causal effect of high school math on labor market outcomes? Journal of Human Resources, 44(1).

Lavy, V. (2008). Do gender stereotypes reduce girls' or boys' human capital outcomes? Evidence from a natural experiment. Journal of Public Economics, 92(10-11):2083-2105.

Pekkarinen, T. (2008). Gender differences in educational attainment: Evidence on the role of the tracking age from a finnish quasi-experiment. Scandinavian Journal of Economics, 110(4):807-825.

PISA Konsortium Deutschland (2006). PISA 2003: Dokumentation der Erhebungsinstrumente. Münster: Waxmann-Verlag. 
Rosenthal, R. and Jacobson, L. (1968). Pygmalion in the classroom: Teacher expectations and student intellectual development. New York: Holt, Rinehart and Winston. 
Table 6: The effect of mother occupation on mathematics test score gap

\begin{tabular}{l|cc}
\hline & $(1)$ & $(2)$ \\
\hline Female & $-40,1 * * *$ & $-46,9 * * *$ \\
& $(3,1)$ & $(7,0)$ \\
101-500 books at pupil's home & $27,3 * * *$ & $26,8 * * *$ \\
& $(3,5)$ & $(3,4)$ \\
$>500$ books at pupil's home & $29,7 * * *$ & $29,6 * * *$ \\
& $(5,6)$ & $(5,5)$ \\
\hline Mother works in social or basic services & & $-0,6$ \\
& & $(6,0)$ \\
Mother works as an employee & & $-1,7$ \\
& & $(6,5)$ \\
\hline Mother works in a high skilled job & & $-0,3$ \\
& & $(8,0)$ \\
Female* mother works in social or basic services & & 3,7 \\
& & $(7,8)$ \\
Female* mother works as an employee & & $16,4 *$ \\
Female* mother has a high skilled job & & $(8,5)$ \\
& & 8,3 \\
\hline Constant & & $(11,7)$ \\
\hline
\end{tabular}

Note: Dependent variable : mathematics test scores. Each estimation is performed with the 5 available measures of test scores, the presented coefficients are the average over the 5 estimations. Standard errors are clustered by school.*,**,*** respectively stand for statistical significance at the 10,5 and $1 \%$ confidence level. Control variables include the pupil's grade, secondary school track, mathematics class size, the share of migrants in the school, school's educational material, a dummy for full-time employment of the father and a dummy for attending kindergarten for less than one year. 